\title{
A Contribution to the Knowledge of Whiteflies (Hemiptera: Aleyrodidae) in Khorasan and Semnan Provinces, Iran
}

\author{
N. SAMIN ${ }^{1}$, H. GHAHARI ${ }^{2}$ and S. BEHNOOD ${ }^{2}$ \\ ${ }^{1}$ Young Researchers and Elite Club, Science and Research Branch, Islamic Azad University, Tehran, Iran \\ ${ }^{2}$ Department of Plant Protection, Yadegar - e-Imam Khomeini (RAH) Branch, \\ Islamic Azad University, Tehran, Iran
}

(Received: 14 April 2015; accepted: 4 June 2015)

\begin{abstract}
Whiteflies (Hemiptera: Aleyrodidae) are some of the most potentially detrimental pests for agricultural crops and the ornamental plant industry in Iran. The present paper deals with the faunistic survey of whiteflies in two provinces of Iran, Khorasan and Semnan. During the survey a total of 16 species from 12 genera were collected and identified. Distribution data are given for the species.
\end{abstract}

Keywords: Hemiptera, Aleyrodidae, whitefly, fauna, host plant, Khorasan, Semnan, Iran.

Whiteflies (Hemiptera: Aleyrodidae) are tiny, sucking insects and the wings and bodies of the adults are covered with a fine, powdery or flour-like white wax (Mound and Halsey, 1978; Hodges and Evans, 2005). There are over than 1560 whitefly species worldwide and they represent an important agricultural pest group (Martin and Lau, 2011).

Several species cause crop losses through direct feeding but the main problem still remains the transmission of different viral plant diseases (Inbar and Gerling, 2008; De Barro et al., 2011). Crop plants are damaged in three ways: direct feeding, virus transmission and fouling with honeydew and sooty moulds. They can cause the plant's foliage changing into yellow and mottled at higher population levels. Additionally excretion of honeydew and sugary sap onto the plant's foliage causes sooty moulds to interfere the photosynthesis (Mound and Halsey, 1978; Gerling, 1990; Byrne and Bellows, 1991). Whiteflies continue to attract great ecological, physiological and agroeconomic interest, primarily because of a few highly polyphagous pest species such as the spiraling whitefly (Aleurodiscus disperses Russell, 1965), the greenhouse whitefly [Trialeurodes vaporariorum (Westwood, 1856)] and the sweet potato whitefly [Bemisia tabaci (Gennadius, 1889)] (Gerling, 1990; Oliveira et al., 2001). In contrast to most oligophagous or monophagous (rarely studied) species, the polyphagous species' diversity and adaptability have facilitated worldwide spread (Costa et al., 1993; Brown et al., 1995; Oliveira et al., 2001).

Several species of whiteflies attack agricultural crops typically have a wide host range and generally occurred in Iran. The fauna of Iranian Aleyrodidae was studied rather

* Corresponding author; e-mail: n_samin63@yahoo.com

0238-1249/\$20.00 (C) 2015 Akadémiai Kiadó, Budapest 
well (Kiriukhin, 1947; Zarrabi, 1998a, b; Ghahari and Hatami, 2001; Manzari, 2005; Manzari and Alemansoor, 2005; Manzari and Moghaddam, 2005; Abd-Rabou and Ghahari, 2005, 2006; Ghahari et al., 2007a, b, 2009a, b; Shahbazvar et al., 2010a, b; Zarei and Asgari, 2013; Zarei et al., 2013). In the mentioned investigations several whitefly species were reported together with their host plants and natural enemies. Several investigation were made regarding to the natural enemies of whiteflies such as genera Encarsia Förster (Abd-Rabou and Ghahari, 2004) and Eretmocerus Haldeman (Hymenoptera: Aphelinidae) (Abd-Rabou et al., 2005).

The objective of this research is to present new data on whitefly fauna of two Iranian provinces, Semnan and Khorasan where the fauna of whiteflies was poorly explored.

Semnan province covers an area of $96,816 \mathrm{~km}^{2}$ and stretches along the Alborz mountain range and borders to Dasht-e Kavir desert in its southern parts. The province is divided into two parts: a mountainous region and the plains at the foot of the mountains.

Khorasan province covers an area of $329,327 \mathrm{~km}^{2}$ and upon the recent dividing, it is consisting of three different parts: northern, Razavi, and southern provinces. It is one of the largest provinces located in East and North-eastern Iran, having boundaries with Afghanistan and Turkmenistan.

\title{
Materials and Methods
}

Whitefly taxonomy relies primarily on morphological characters of the fourth instar (Mound and Halsey, 1978; Ma et al., 2007). Therefore, the puparia of whiteflies were collected on the leaves of their host plants from natural habitats and agricultural fields of Semnan and Khorasan provinces. The specimens were studied using the technical and slide making procedure of Martin (1985) and are deposited in the collections of the authors. The classification and nomenclature suggested by Bink-Moenen (1983), Evans (2007) and Martin and Mound (2007) have been followed, and distribution data are according to Martin et al. (2000) and Evans (2007).

\section{Results}

In total sixteen whitefly species from twelve genera were collected and identified from different regions of Semnan and Khorasan provinces. Species list with distributional data is given below.

\author{
Family Aleyrodidae Westwood, 1840 \\ Subfamily Aleyrodinae Westwood, 1840 \\ Genus Aleurocanthus Quaintance and Baker, 1914
}

\section{Aleurocanthus woglumi Ashby, 1915}

Material examined: Semnan province: Shahrood, $1312 \mathrm{~m}, 35^{\circ} 30^{\prime} \mathrm{N} 55^{\circ} 30^{\prime} \mathrm{E}$, on $\mathrm{Hi}$ biscus rosa-sinensis (Malvaceae), 3 specimens, 14. VI. 2011. 
General distribution: Virtually worldwide. USA, Mexico, Guatemala, Cuba, Honduras, Nicaragua, El Salvador, Panama, Costa Rica, Venezuela, Colombia, Brazil, Argentina, Paraguay, Peru, Uruguay, Jamaica, Puerto Rico, Egypt, England, France, Iran, Israel, Italy, Spain, Russia and adjacent countries, Uganda, Kenya, South Africa, Tanzania, China, India, Philippines, Malaysia, Vietnam, Taiwan Thailand, Australia, Indonesia, New Zealand, Hawaii.

\section{Aleurocanthus zizyphi Priesner and Hosny 1934}

Material examined: Khorasan province: Mashhad, $991 \mathrm{~m}, 36^{\circ} 17^{\prime} \mathrm{N} 59^{\circ} 40^{\prime} \mathrm{E}$, on Ziziphus spina-christi (Rhamnaceae), 2 specimens, 14. VI. 2011.

General distribution: Egypt, Iran, Jordan, Chad, Congo, Ivory Coast, Kenya, Nigeria, South Africa, Uganda.

\section{Genus Aleurolobus Quaintance and Baker 1914}

\section{Aleurolobus olivinus (Silvestri) 1911}

Material examined: Semnan province: Semnan, $1163 \mathrm{~m}, 35^{\circ} 20^{\prime} \mathrm{N} 53^{\circ} 20^{\prime} \mathrm{E}$, on Olea sp. (Oleaceae), 2 specimens, 12. IV. 2010. Spain.

General distribution: China, Cyprus, Egypt, France, Iran, Israel, Italy, Morocco,

\section{Genus Aleyrodes Latreille 1796}

\section{Aleyrodes singularis Danzig 1964}

Material examined: Khorasan province: Kashmar, $1060 \mathrm{~m}, 35^{\circ} 26^{\prime} \mathrm{N} 58^{\circ} 29^{\prime} \mathrm{E}$, on Lactuca sp. (Asteraceae), 3 specimens, 11. VII. 2011.

General distribution: Azores, Canary Islands, Iran, Jordan, Russia and adjacent countries.

\section{Genus Asterobemisia Trehan 1940}

\section{Asterobemisia trifolii (Danzig) 1966}

Material examined: Semnan province: Shahrood, $1312 \mathrm{~m}, 35^{\circ} 30^{\prime} \mathrm{N} 55^{\circ} 30^{\prime} \mathrm{E}$, on Trifolium lupinaster (Fabaceae), 1 specimen, 11. IV. 2010.

General distribution: Caucasus, Iran, Russia.

\section{Genus Bemisia Quaintance and Baker 1914}

\section{Bemisia afer (Priesner and Hosny) 1934}

Material examined: Khorasan province: Bojnord, $1070 \mathrm{~m}, 37^{\circ} 35^{\prime} \mathrm{N} 57^{\circ} 20^{\prime} \mathrm{E}$, on Gossypium hirsutum (Malvaceae), 2 specimens, 14. VI. 2012.

General distribution: Australia, Brazil, Cameroon, Chad, China, Congo, Egypt, Iran, Israel, Italy, Spain, Guinea, India, Ivory Coast, Kenya, Korea, Madagascar, New Guinea, Niger, Nigeria, Sierra Leon, South Africa, Sudan, Pakistan, Uganda, Zaire. 


\section{Bemisia tabaci (Gennadius 1889)}

Material examined: Semnan province: Shahmirzad, $1944 \mathrm{~m}, 35^{\circ} 46^{\prime} \mathrm{N} 53^{\circ} 19^{\prime} \mathrm{E}$, on Populus nigra (Salicaceae), 4 specimens, 24. IV. 2009.; Garmsar, $848 \mathrm{~m}, 35^{\circ} 00^{\prime} \mathrm{N}$ $52^{\circ} 20^{\prime} \mathrm{E}$, on Lycopersicum esculentum (Solanaceae), 6 specimens, 8. III. 2010.; Shahrood, $1312 \mathrm{~m}, 35^{\circ} 30^{\prime} \mathrm{N} 55^{\circ} 30^{\prime} \mathrm{E}$, on Euphorbia bungei (Euphorbiaceae), 2 specimens, 11. IV. 2010; Khorasan province: Mashhad, $991 \mathrm{~m}, 36^{\circ} 17^{\prime} \mathrm{N} 59^{\circ} 40^{\prime} \mathrm{E}$, on Petunia hybrida (Solanaceae), 2 specimens, 14. VI. 2011.; Sabzevar, $1023 \mathrm{~m}, 36^{\circ} 12^{\prime} \mathrm{N} 57^{\circ} 35^{\prime} \mathrm{E}$, on Althaea officinalis (Malvaceae), 5 specimens, 2. X. 2011.

General distribution: Cosmopolitan species.

\section{Genus Bulgarialeurodes Corbett 1936}

\section{Bulgarialeurodes cotesii (Maskell) 1895}

Material examined: Semnan province: Semnan, $1163 \mathrm{~m}, 35^{\circ} 20^{\prime} \mathrm{N} 53^{\circ} 20^{\prime} \mathrm{E}$, on Rosa canina (Rosaceae), 4 specimens, 12. IV. 2010; Khorasan province: Mashhad, $1182 \mathrm{~m}$, 36 ${ }^{\circ} 17^{\prime} \mathrm{N} 59^{\circ} 40^{\prime} \mathrm{E}$, on Rosa canina (Rosaceae), 7 specimens, 6 VIII. 2009.

General distribution: Afghanistan, Bulgaria, Iran, Pakistan, Romania, Turkmenistan, Russia and adjacent countries, former Yugoslavia.

\section{Genus Dialeurodes Cockerell 1902}

\section{Dialeurodes citri (Ashmead) 1885}

Material examined: Khorasan province: Kashmar, $1060 \mathrm{~m}, 35^{\circ} 26^{\prime} \mathrm{N} 58^{\circ} 29^{\prime} \mathrm{E}$, on Punica granatum (Punicaceae), 2 specimens, 11. VI. 2011.

General distribution: Afghanistan, China, Cuba, Dominican Republic, El Salvador, France, Greece, Guam, Haiti, Hawaii, Honduras, Hong Kong, India, Iran, Italy, Japan, Korea, Macau, Mexico, Pakistan, Panama, Philippines, Portugal, Puerto Rico, Taiwan, Thailand, Turkey, USA.

\section{Genus Dialeurolonga Dozier 1928}

\section{Dialeurolonga maculata (Singh) 1931}

Material examined: Khorasan province: Mashhad, $1182 \mathrm{~m}, 36^{\circ} 17^{\prime} \mathrm{N} 59^{\circ} 40^{\prime} \mathrm{E}$, on Ficus religiosa (Moraceae), 1 specimen, 14. VI. 2011.

General distribution: India, Iran, Pakistan.

\section{Genus Neomaskellia Quaintance and Baker 1913}

\section{Neomaskellia bergii (Signoret) 1868}

Material examined: Semnan province: Semnan, 1163 m, 35²0'N 5320'E, on Sorghum halepense (Poaceae), 2 specimens, 2. III. 2008.

General distribution: Australia, Caroline Islands, Central African Republic, Congo, Fiji, Gambia, India, Iran, Japan, Java, Mauritius, New Zealand, Senegal, Sierra Leon, South Africa, Sudan, Taiwan, Tanzania, Thailand, Uganda, Zaire. 


\section{Genus Ramsesseus Zahradnik 1970}

\section{Ramsesseus follioti Zahradnik 1970}

Material examined: Khorasan province: Sabzevar, $1023 \mathrm{~m}, 36^{\circ} 12^{\prime} \mathrm{N} 57^{\circ} 35^{\prime} \mathrm{E}$, on Acacia sp. (Fabaceae), 1 specimen, 2. X. 2011.

General distribution: Egypt, Iran, Iraq.

\section{Genus Siphoninus Silvestri 1915}

\section{Siphoninus phillyreae (Haliday) 1835}

Material examined: Semnan province: Garmsar, $850 \mathrm{~m}, 35^{\circ} 00^{\prime} \mathrm{N} 52^{\circ} 20^{\prime} \mathrm{E}$, on $\mathrm{Pu}$ nica granatum (Punicaceae), 3 specimens, 29. III. 2010; Khorasan province: Bojnord, 1070 m, 37² $35^{\prime} \mathrm{N} 57^{\circ} 20^{\prime} \mathrm{E}$, on Fraxinus excelsior (Oleaceae), 4 specimens, 14. VI. 2012.

General distribution: Australia, Bulgaria, Cameroon, Corsica, Cyprus, England, Egypt, Eritrea, Ethiopia, Finland, France, Germany, Greece, Hungary, Iran, Ireland, Israel, Italy, Java, Jordan, Mexico, Peru, Spain, Sudan, Syria, Taiwan, USA, Russia and adjacent countries, former Yugoslavia, Venezuela, Zaire.

\section{Genus Trialeurodes Cockerell 1902}

\section{Trialeurodes packardi (Morrill) 1903}

Material examined: Semnan province: Shahmirzad, $1944 \mathrm{~m}, 35^{\circ} 46^{\prime} \mathrm{N} 53^{\circ} 19^{\prime} \mathrm{E}$, on Juglans regia (Juglandaceae), 2 specimens, 4. IV. 2010.

General distribution: Canada, Hungary, Iran, Korea, USA.

\section{Trialeurodes ricini (Misra) 1924}

Material examined: Semnan province: Semnan, $1163 \mathrm{~m}, 35^{\circ} 20^{\prime} \mathrm{N} 53^{\circ} 20^{\prime} \mathrm{E}$, on Ricinus communis (Euphorbiaceae), 4 specimens, 5. X. 2009; Khorasan province: Kashmar, $1060 \mathrm{~m}, 35^{\circ} 26^{\prime} \mathrm{N} 58^{\circ} 29^{\prime} \mathrm{E}$, on Gossypium hirsutum (Malvaceae), 2 specimens, 11. VII. 2011.

General distribution: Cameroon, Chad, Gabon, India, Iran, Israel, Ivory Coast, Madagascar, Malaya, Malaysia, Nigeria, Pakistan, Saudi Arabia, Sierra Leon, Sri Lanka, Sudan, Thailand, Turkey, Uganda, Zaire, Zimbabwe.

\section{Trialeurodes vaporariorum (Westwood) 1856}

Material examined: Semnan province: Shahmirzad, $1944 \mathrm{~m}, 35^{\circ} 46^{\prime} \mathrm{N} 53^{\circ} 19^{\prime} \mathrm{E}$, on Verbena officinalis (Verbenaceae), 3 specimens, 7. VI. 2010.; Shahrood, $1312 \mathrm{~m}, 35^{\circ} 30^{\prime} \mathrm{N}$ $55^{\circ} 30^{\prime} \mathrm{E}$, on Amaranthus blitoides (Amaranthaceae), 2 specimens, 10. IV. 2010.; Garmsar, $848 \mathrm{~m}, 35^{\circ} 00^{\prime} \mathrm{N} 52^{\circ} 20^{\prime} \mathrm{E}$, on Malva montana (Malvaceae), 4 specimens, 8. III. 2010; Khorasan province: Mashhad, $991 \mathrm{~m}, 36^{\circ} 17^{\prime} \mathrm{N} 59^{\circ} 40^{\prime} \mathrm{E}$, on Lavandula vera (Labiatae), 2

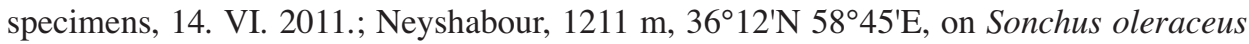
(Asteraceae), 7 specimens, 16. IX. 2011.; Quchan, 1273 m, 3709'N 58³4'E, on Chenopodium album (Chenopodiaceae), 1 specimen, 18. IX. 2011.

General distribution: Cosmopolitan species. 


\section{Discussion}

In this research, among the 16 species, 5 species were collected just from Semnan province, 6 species just from Khorasan province, and 5 species from the both provinces (Figs. 1 and 2). Although Semnan and Khorasan provinces are nearly dry regions, a rather diverse fauna of whitefly were collected. Among the different sampled regions, Jangal-e Abr in Shahrood contains more diverse flora and consequently diverse whitefly species. Future sampling surveys of the area may result to new findings on this taxon.

During the investigation 17 plant families were identified as host plants of whiteflies. Plant species from Malvaceae family were common host of several whitefly species which were recorded in five different sampling sites in both provinces.

As we predicted, two species, B. tabaci and T. vaporariorum are more common than the others and well distributed in all of the natural habitats of the sampled regions. Both of them are serious pests especially in vegetables and ornamental crops (Mound and Halsey, 1978; Brown and Bird, 1992; van Lenteren and Martin, 2000), and vectors of over than 60 plant viruses in the genera Geminivirus, Clostevirus, Nepovirus, Carlarvirus, Potyvirus and a rod-shaped DNA virus (Fauquet and Fargette, 1990; Markham et al., 1994; Alegbejo and Banwo, 2005). In Iran, B. tabaci and B. argentifolii Bellows and Perring (Ghahari et al., 2008) are serious and occasionally destructive pests in cotton fields, while $T$. vaporariorum is an economic pest of ornamental plants in most greenhouses (Ghahari et al., 2007a, b).

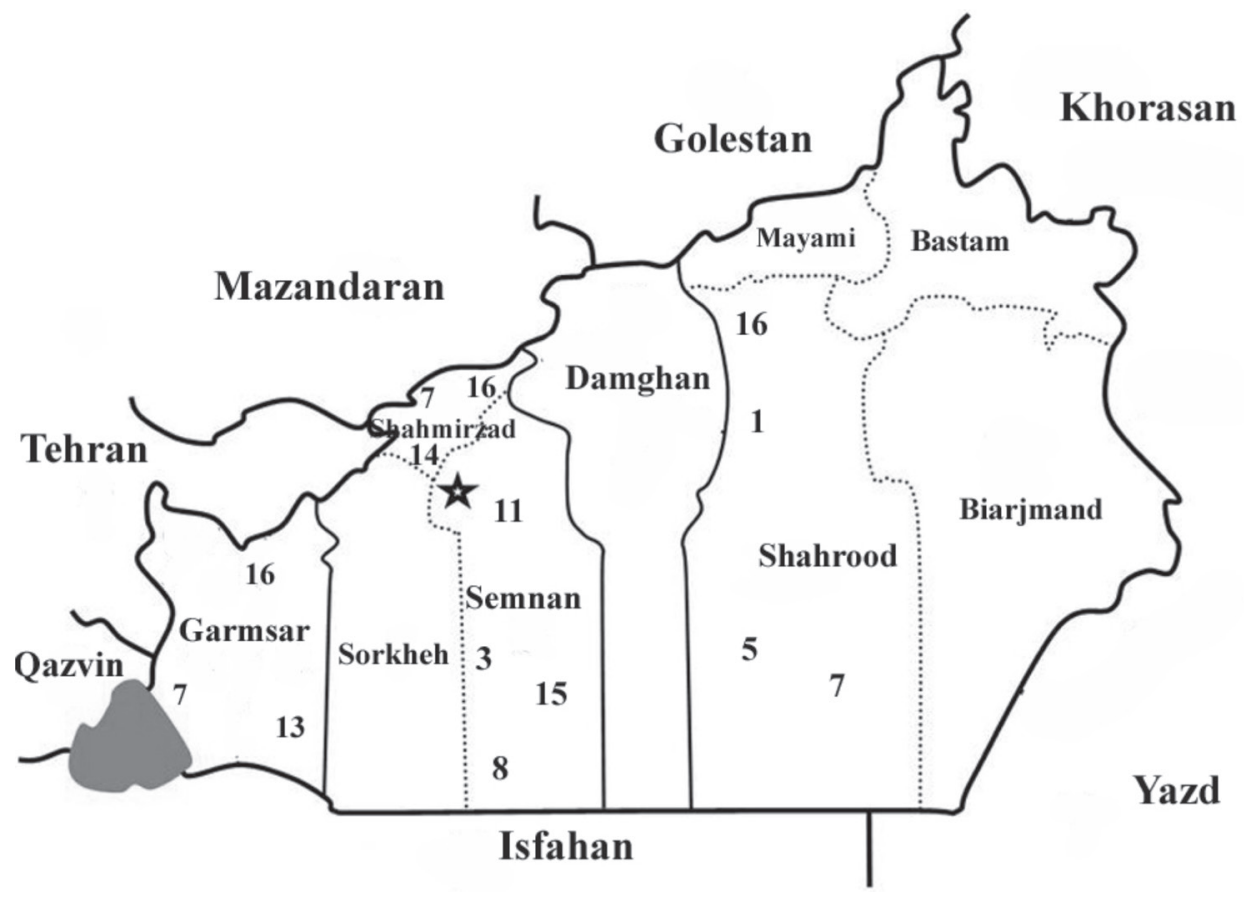

Fig. 1. Semnan province with distribution data of Aleyrodidae 


\section{Turkmenistan}

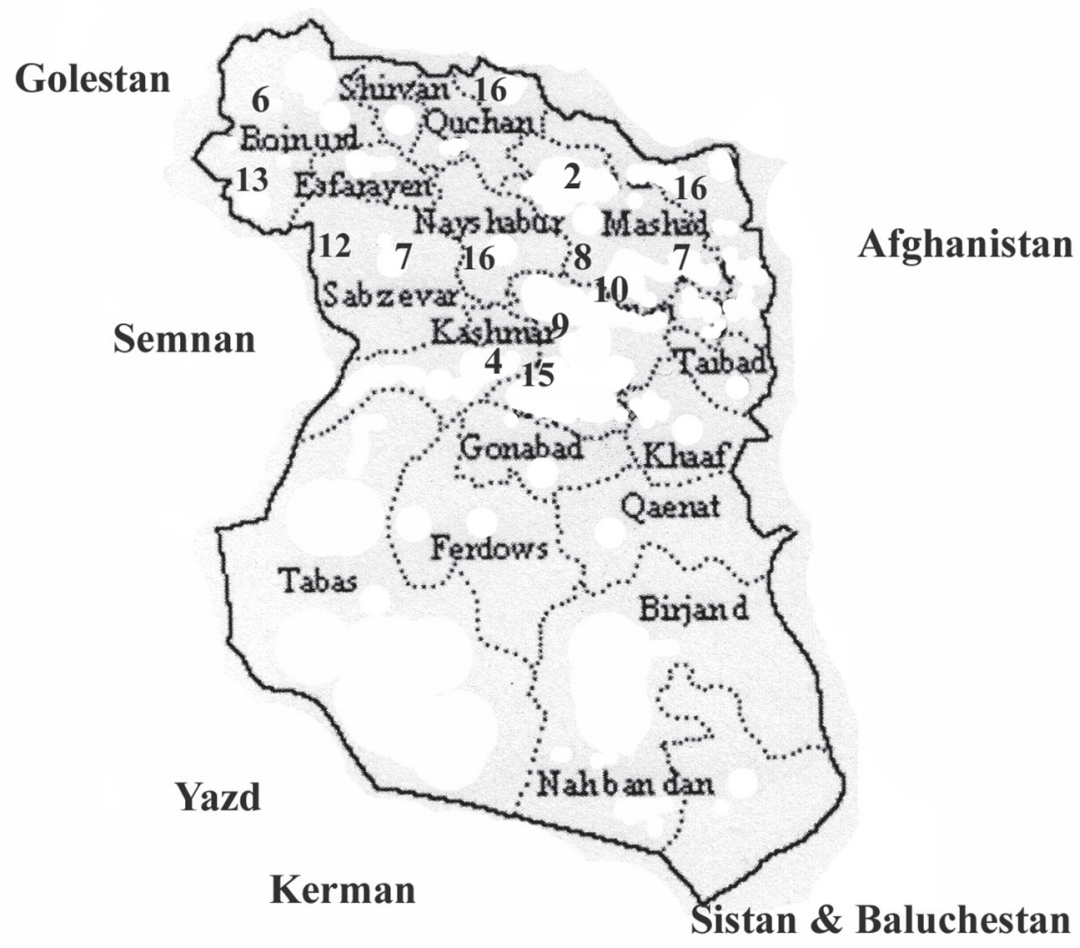

Fig. 2. Khorasan province with distribution data of Aleyrodidae

The results indicate that Semnan and Khorasan provinces can be characterized with a diverse whitefly fauna. Despite the limited sampling sites which includes only natural habitats future survey of various agricultural fields of this regions could give interesting findings.

\section{Acknowledgements}

The authors are grateful to R. Bink-Moenen (the Netherlands), S. Abd-Rabou (Egypt) and E. Danzig (Russia) for their valuable helps in progress of this project. We are grateful to G. Evans (USA) and H. Ghahari (Iran) for providing the necessary papers, and the unknown reviewer for invaluable comments. The research was supported by Islamic Azad University (Yadegar - e-Imam Khomeini (RAH) Branch). 


\section{Literature}

Abd-Rabou, S. and Ghahari, H. (2004): A revision of Encarsia (Hymenoptera: Aphelinidae) species from Iran. Egyptian J. Agricultural Research 82, 647-684.

Abd-Rabou, S. and Ghahari, H. (2005): Host plants and distribution of whiteflies (Homoptera: Aleyrodidae) in Iran. Egyptian J. Agricultural Research 83, 179-196.

Abd-Rabou, S. and Ghahari, H. (2006): The whitefly fauna of Iran (Hemiptera: Sternorrhyncha: Aleyrodidae). Trends in Entomology (Review) 5, 47-69.

Abd-Rabou, S., Ghahari, H. and Evans, G. (2005): Iranian Eretmocerus species (Hymenoptera: Chalcidoidea: Aphelinidae) parasitoids of whiteflies (Sternorrhyncha: Aleyrodidae). Mitteilungen des Internationalen Entomologischen Vereins 30, 157-176.

Alegbejo, M. D. and Banwo, O. O. (2005): Hosts of Bemisia tabaci Genn. in Northern Nigeria. Acta Phytopathol. et Entomol. Hung. 40, 417-422.

Bink-Moenen, R. M. (1983): Revision of the African whiteflies (Aleyrodidae). Monografieen van de Nederlandse Entomologische Vereniging, Amsterdam 10, 1-211.

Brown, J. K. and Bird, J. (1992): Whitefly transmitted geminiviruses and associated disorders in the Americas and the Carribean Basin. Plant Disease 76, 220-225.

Brown, J. K., Frohlich, D. R. and Rosell, R. C. (1995): The sweetpotato or silverleaf whiteflies: biotypes of Bemisia tabaci or a species complex? Annual Rev. Entomol. 40, 511-534.

Byrne, D. N. and Bellows, T. S. (1991): Whitefly biology. Annual Rev. Entomol. 36, 431-457.

Costa, H. S., Johnson, M. W., Ullman, D. E. and Tabashnik, B. E. (1993): Squash silverleaf symptoms, induced by immature, but not adult, Bemisia tabaci. Phytopathology 83, 763-766.

De Barro, P. J., Liu, S.-S., Boykin, L. M. and Dinsdale, A. B. (2011): Bemisia tabaci: A statement of species status. Annual Rev. Entomol. 56, 1-19.

Evans, G. (2007): Last modified November 28, 2007, Online: The whiteflies of the world and their host plants and natural enemies. Version 2007-11-28, (http://www.sel.barc.usda.gov:591/1WF/whitefly_catalog.htm)

Fauquet, C. and Fargette, D. (1990): African cassava mosaic virus: Etiology, epidemiology and control. Plant Disease 74, 404-411.

Gerling, D. (1990): Whiteflies: Their Bionomics, Pest Status and Management. Intercept, Wimborne, UK, pp. $1-348$.

Ghahari, H. and Hatami, B. (2001): Faunistic and taxonomic surveys of whiteflies (Homoptera: Aleyrodidae) in Isfahan Province. Appl. Entomol. and Phytopathol. 69, 141-170 [in Persian with English summary].

Ghahari, H., Mohebbi, H. R. and Parvanak, K. (2007a): Host plants of whiteflies (Homoptera: Aleyrodidae) in many regions of Iran. J. Plant and Ecosystem 9, 1-14 [in Persian with English summary].

Ghahari, H., Abd-Rabou, S., Ostovan, H. and Samin, N. (2007b): Whiteflies (Homoptera: Aleyrodidae) and their host plants in Golestan province, Iran. J. Plant and Ecosystem 12, 17-28. [in Persian with English summary].

Ghahari, H., Sakenin, H. and Ostovan, H. (2008): Morphological and biological studies on different life stages of Bemisia argentifolii Bellows and Perring (Homoptera: Aleyrodidae) on Gossypium hirsutum. Agricultural Science 18, 205-218 [in Persian with English summary].

Ghahari, H., Ko, C.-C. and Ostovan, H. (2009a): Three new records of Aleuroviggianus Iaccarino (Hemiptera: Sternorrhyncha: Aleyrodidae) from Iran with identification key. Munis Entomology and Zoology 4, 117-120.

Ghahari, H., Abd-Rabou, S., Zahradnik, J. and Ostovan, H. (2009b): Annotated catalogue of whiteflies (Hemiptera: Sternorrhyncha: Aleyrodidae) from Arasbaran, Northwestern Iran. J. Entomology and Nematology 1, 7-18.

Hodges, G. S. and Evans, G. (2005): An identification guide to the whiteflies (Hemiptera: Aleyrodidae) of the southeastern United States. Florida Entomologist 88, 518-534.

Inbar, M. and Gerling, D. (2008): Plant-mediated interactions between whiteflies, herbivores, and natural enemies. Annual Rev. Entomol. 53, 431-448.

Kiriukhin, G. (1947): Quelques Aleurododea de 1'Iran. Applied Entomology and Phytopathology 5, 8-10 [in Persian, 5, 22-28; French summary]. 
Ma, D. Y., Gorman, K., Devine, G., Luo, W. C. and Denholm, I. (2007): The biotype and insecticide-resistance status of whiteflies, Bemisia tabaci (Hemiptera: Aleyrodidae), invading cropping systems in Xinjiang Uygur Autonomous Region, northwestern China. Crop Protection 26, 612-617.

Manzari, S. (2005): The first report of the genus and species of the whitefly, Aleuromarginatus tephrosiae (Hem.: Aleyrodidae), from Iran. J. Entomological Society of Iran 25, 73-74.

Manzari, S. and Alemansoor, H. (2005): A new species of Acaudaleyrodes Takahashi (Hemiptera: Aleyrodidae) from Iran, with a key to species of the genus. Zootaxa 829, 1-6.

Manzari, S. and Moghaddam, M. (2005): The first report of the genus and species of the whitefly, Zaphanera cyanotis (Hem.: Aleyrodidae), from Iran. J. Entomological Society of Iran 25, 83-84.

Markham, P. G, Bedford, I. D., Liu, S. and Pinner, M. S. (1994): The transmission of geminiviruses by Bemisia tabaci. Pesticide Science 42, 123-128.

Martin, J. H. (1985): The whitefly of the Guinea (Homoptera: Aleyrodidae). Bulletin of British Museum Natural History 50, 303-351.

Martin, J. H. and Mound, L. A. (2007): An annotated check list of whiteflies (Insecta: Hemiptera: Aleyrodidae). Zootaxa 1492, 1-84.

Martin, J. H. and Lau, C. S. K. (2011): The Hemiptera-Sternorrhyncha (Insecta) of Hong Kong, China - an annotated inventory citing voucher specimens and published records. Zootaxa 2847, 1-122.

Martin, J. H., Mifsud, D. and Rapisarda, C. (2000): The whiteflies (Hemiptera: Aleyrodidae) of Europe and the Mediterranean Basin. Bulletin of Entomological Research 90, 407-448.

Mound, L. A. and Halsey, S. H. (1978): Whitefly of the World. British Museum (Natural History). John Wiley and Sons, Chichester, pp. 1-340.

Oliveira, M. R. V., Henneberry, T. J. and Anderson, P. (2001): History, current status, and collaborative research projects for Bemisia tabaci. Crop Protection 20, 709-723.

Shahbazvar, N., Sahragard, A., Manzari, S., Hosseini, R. and Hajizadeh, J. (2010a): A faunal study of whiteflies (Hemiptera: Aleyrodidae) and their parasitoids in Guilan province, Iran. Entomofauna 31, 269-284.

Shahbazvar, N., Manzari, S., Sahragard, A., Hosseini, R. and Hajizadeh, J. (2010b): A new species of Aleuroclava Singh (Hemiptera: Aleyrodidae) from Iran. Zootaxa 2428, 64-68.

van Lenteren, J. C. and Martin, N. A. (2000): Biological control of whiteflies. In: R. Albajes, M. Gullino, J. C. van Lenteren and Y. Elad (eds): Integrated Pest and Disease Management in Greenhouse Crops., Kluwer Publishers, Dordrecht, pp.1-568.

Zarei, A. and Asgari, Sh. (2013): A study on the whiteflies (Hemiptera: Aleyrodidae) and their parasitoids in southern Tehran, Iran. Calodema 267, 1-4.

Zarei, A., Farhangian, S. and Monem, R. (2013): A study on the host plants of whiteflies (Hemiptera: Aleyrodidae) in some regions of Tehran, Iran. Calodema 265, 1-3.

Zarrabi, M. (1998a): Aleyrodid species of forest and pasturage plants of Fars province. Proc. of the $13^{\text {th }}$ Iranian Plant Protection Congress, Karaj, 182 p.

Zarrabi, M. (1998b): Aleyrodid fauna of Hamedan and suburbs. Proc. of the $13^{\text {th }}$ Iranian Plant Protection Congress, Karaj, 224 p. 